\title{
Karakteristik Fisik Beras Analog Instan Berbasis Tepung Jagung dengan Penambahan k-Karagenan dan Konjak
}

\author{
Physical Characteristics of Corn-Based Instant Analog Rice with Addition of k-Carrageenan and Konjac \\ Indah Kurniasari ${ }^{1,2}$, Feri Kusnandar ${ }^{1 *}$, Slamet Budijanto ${ }^{1}$ \\ 1Program Studi IImu Pangan, Departemen Ilmu dan Teknologi Pangan, Fakultas Teknologi Pertanian, Institut \\ Pertanian Bogor, Jl. Raya Darmaga, Bogor 16680, Indonesia \\ 2Pusat Teknologi Agroindustri, Badan Pengkajian dan Penerapan Teknologi, \\ LAPTIAB, Kawasan Puspiptek, Serpong, 15314, Indonesia \\ *Penulis korespondensi: Feri Kusnandar, Email: fkusnandar@gmail.com
}

Tanggal submisi: 11 Juli 2019; Tanggal penerimaan: 5 November 2019

\begin{abstract}
ABSTRAK
Beras analog instan merupakan salah satu bentuk pengembangan produk dari beras analog yang siap dikonsumsi tanpa perlu dimasak terlebih dahulu, melainkan hanya perlu direndam dalam air mendidih selama 3-5 menit. Tantangan utama dalam pengembangan beras analog instan adalah untuk menurunkan waktu rehidrasi dengan tetap menjaga keutuhan dan tekstur dari nasi yang dihasilkan. Hidrokoloid berupa к-karagenan dan konjak dengan variasi konsentrasi $0,5-10,0 \%$, baik secara tunggal maupun kombinasi ditambahkan ke dalam formula beras analog berbasis tepung jagung. Kemudian, pengaruh penambahan hidrokoloid tersebut terhadap karakteristik fisik dari beras analog instan dievaluasi. Penambahan к-karagenan dan konjak secara kombinasi pada konsentrasi masing-masing 5\% (KK10) menunjukkan hasil terbaik. Beras analog instan tersebut memiliki degree of breakage dan densitas kamba yang rendah, yaitu 2,02\% dan 0,39 g/mL, dengan mikrostruktur butiran beras yang lebih berongga dibandingkan kontrol atau kombinasi lainnya. Beras analog instan KK10 dapat direhidrasi dengan perendaman dalam air mendidih selama 3,5 menit. Nasi yang dihasilkan memiliki keutuhan butiran yang tinggi, dengan nilai hardness, springiness, dan chewiness sebesar 548,14 g; 0,86; dan 229,76 g.
\end{abstract}

Kata kunci: Beras analog; k-karagenan; hidrokoloid; beras instan; lonjak

\begin{abstract}
Instant analog rice is a form of product development from analog rice that is ready for consumption without the need to be cooked first but only needs to be soaked in boiling water for 3-5 minutes. The main challenge in developing instant analog rice is to reduce rehydration time while maintaining the integrity and texture of the rice produced. Hydrocolloids in the form of $\mathrm{k}$-carrageenan and konjac with concentrations of $0.5-10.0 \%$, both as a single additive and in combination, were added to the corn-based analog rice formula. Then, their effects on the physical characteristics of the instant analog rice were studied. The addition of $\mathrm{k}$-carrageenan and konjac in combination at a concentration of $5 \%$ each (KK10) showed the best results. This instant analog rice had a lower degree of breakage and bulk density, $2.02 \%$ and $0.39 \mathrm{~g} / \mathrm{mL}$, respectively. It showed a more hollow rice microstructure than the control and other combinations. KK10 instant analog rice can be rehydrated by soaking in boiling water for 3.5 minutes. The rehydrated rice had high grain integrity, with hardness, springiness, and chewiness values of $548.14 \mathrm{~g} ; 0.86$; and $229.76 \mathrm{~g}$, respectively.
\end{abstract}

Keywords: Analog rice; k-carrageenan; hydrocolloid; instant rice; konjac

DOI: http://doi.org/10.22146/agritech.47491

ISSN 0216-0455 (Print), ISSN 2527-3825 (Online) 


\section{PENDAHULUAN}

Beras analog merupakan produk pangan dengan bentuk menyerupai beras, terbuat dari sumber karbohidrat selain beras padi yang diolah melalui proses ekstrusi (Budijanto dan Yuliana, 2015). Formulasi beras analog dari berbagai sumber karbohidrat telah banyak dikembangkan, di antaranya dari sorgum dan jagung (Budijanto dan Yuliyanti, 2012), jagung putih dan (Noviasari dkk., 2013), sorgum dan rempah (Rasyid dkk., 2017), campuran sorgum, sagu, pati jagung, dan mocaf (Noviasari dkk., 2017b), campuran jagung putih dan kedelai (Noviasari dkk., 2015) serta jagung, sorgum, dan sagu (Budijanto dkk., 2017).

Pengembangan beras analog menjadi produk instan ditujukan bagi masyarakat di perkotaan yang sibuk, yang tinggal jauh dari tempat tersedianya beras yang cukup, atau yang sedang mengalami bencana alam. Definisi beras analog instan dapat merujuk pada beras instan pada umumnya, yaitu beras yang dapat dikonsumsi hanya dengan perendaman dalam air mendidih selama 3-5 menit (Patent No. US 2001/0006696 A1, 2001). Beras analog instan memiliki ciri khas berupa butiran berasnya yang lebih berpori, yang akan memudahkan air berpenetrasi ke dalamnya saat proses rehidrasi. Beras analog instan juga memiliki densitas kamba yang rendah dengan daya serap air yang tinggi (Wongsa dkk., 2017). Apabila direndam dalam air mendidih, beras analog instan memiliki waktu rehidrasi yang singkat dan kapasitas rehidrasi yang tinggi (Bui dkk., 2018).

Tantangan yang dihadapi dalam pengembangan beras analog instan tidak jauh berbeda dengan beras instan dari beras padi, yaitu untuk menurunkan waktu rehidrasi dengan tetap menjaga kualitas tekstural dari nasi. Nasi yang dihasilkan dari beras instan pada umumnya memiliki tekstur yang tidak sebaik nasi yang dimasak dengan cara konvensional (Prasert dan Suwannaporn, 2009). Kondisi struktur butiran beras analog yang tidak sama dengan beras dari padi juga menjadikan beras analog instan mudah hancur pada saat sebelum dan setelah rehidrasi. Namun demikian, pembuatan beras analog instan yang melibatkan proses ekstrusi memungkinkan pemberian bahan tambahan pangan dalam formulasinya, yang dapat ditujukan untuk memperbaiki karakteristik fisik dan fungsional dari nasi instan. Wang dkk. (2013) menggunakan emulsifier (gliserol monostrearat, lesitin kedelai, dan sodium stearoyl lactylate), pengental berupa hidrokoloid (xanthan gum, gum arabik, dan sodium alginat), serta tepung beras ketan untuk memperbaiki mutu beras artifisial instan dari bahan tepung beras yang dibentuk melalui proses ekstrusi. Hasilnya menunjukkan adanya peningkatan tekstur dan kemampuan rehidrasi beras artifisial instan dengan penambahan emulsifier dan pengental.

Karagenan telah digunakan secara luas sebagai bahan tambahan pangan karena sifat fungsionalnya sebagai pembentuk gel, penstabil, pengental, dan pengikat air. Selain itu karagenan juga terbukti mampu meningkatkan palatibilitas berbagai pangan olahan (Blakemore, 2016). Pada formula beras analog, karagenan digunakan sebagai binder atau bahan pengikat (Mishra dkk., 2012) seperti yang diaplikasikan pada pembuatan beras analog berbahan mocaf, tepung garut, dan kacang merah (Wahjuningsih dan Susanti, 2018) dan beras analog dari tepung jagung putih (Herawati, 2015). Karagenan jenis kappa paling banyak dimanfaatkan karena ketersediaannya di alam yang lebih melimpah dibandingkan jenis karagenan lain. Namun demikian, gel yang dihasilkan bersifat kaku dan rapuh (Naligar, 2016). Hal tersebut dapat diperbaiki dengan penambahan konjak, yang dapat berinteraksi secara sinergis membentuk gel yang lebih elastis (Penroj dkk., 2005; Kaya dkk., 2015). Konjak sendiri juga dilaporkan dapat meningkatkan sifat fisik dan sensori pada mie terigu berprotein rendah (Zhou dkk., 2013), dan pada mie dari bahan tepung buckwheat (Han dkk., 2014).

Seperti halnya hidrokoloid lain, $\mathrm{k}$-karagenan dan konjak memiliki banyak gugus hidrofilik yang membuatnya memiliki afinitas terhadap air yang tinggi (Marthur, 2012). Meskipun belum ada yang melaporkan pemanfaatan $\mathrm{k}$-karagenan dan konjak secara langsung untuk memperpendek waktu rehidrasi beras analog instan, beberapa penelitian telah melaporkan aplikasi hidrokoloid untuk menurunkan cooking time yang dibutuhkan produk pangan untuk dapat siap dikonsumsi. Penambahan $2 \%$ guar gum dapat mempercepat cooking time mie dari campuran mocaf, tepung beras, dan tepung jagung (Ratnawati dan Afifah, 2018). Penurunan cooking time mie dari tepung terigu juga dilaporkan oleh Tan dkk. (2018) dengan semakin meningkatnya konsentrasi karagenan, xanthan gum, dan locust bean gum. Peningkatan konsentrasi hidrokoloid tersebut berpengaruh kepada peningkatan kapasitas penyerapan air adonan, yang diduga berkaitan dengan banyaknya gugus hidroksil pada struktur hidrokoloid yang meningkatkan interaksi dengan air melalui pembentukan ikatan hidrogen. Berdasarkan fungsi $\mathrm{k}$-karagenan sebagai binder dalam produk ekstrusi, kemampuan penyerapan air, peningkatan kualitas tekstur produk pangan, serta kemungkinan adanya interaksi sinergisme dengan konjak, penelitian ini menggunakan $\mathrm{k}$-karagenan dan konjak untuk memperoleh formula beras analog instan yang dapat direhidrasi dengan cepat, serta memiliki keutuhan butiran nasi dan kualitas tekstural yang tinggi. 
Penelitian ini bertujuan untuk mengevaluasi potensi pembuatan beras analog instan dari bahan tepung jagung, dengan penambahan $\mathrm{k}$-karagenan dan konjak secara tunggal dan kombinasi, serta menentukan jenis dan konsentrasi $\mathrm{k}$-karagenan dan konjak yang sesuai untuk meningkatkan sifat fungsional dan penampilan fisik nasi analog instan yang dihasilkan.

\section{METODE PENELITIAN}

\section{Bahan}

Bahan yang digunakan terdiri dari tepung jagung kuning varietas BISI- 2 berukuran 40 mesh dari PT Kediri Matahari Corn Mills, pati sagu, dan gliserol monostearat (GMS), serta k-karagenan dan tepung konjak yang diperoleh dari CV Nura Jaya.

\section{Alat}

Peralatan proses yang digunakan antara lain ekstruder ulir ganda (Berto Industry BEX-DS-2256), pengering kabinet (Terada Seisakusho ND4-60 SP), steamer Masindo, dan fluidized dryer (BPPT, Serpong). Alat analisa yang digunakan di antaranya chromameter (CR-400 Minolta, USA), scanning electron microscope (SEM) (Jeol JSM-6510LA, Tokyo, Jepang) dan texture analyzer (TA.XTplus Stable Micro Systems, UK).

\section{Pembuatan Beras Analog Instan}

Tepung jagung dan pati sagu dicampur dengan perbandingan 90:10, lalu ditambahkan 2\% GMS. K-karagenan dan konjak kemudian ditambahkan secara tunggal dan kombinasi (1:1) dengan konsentrasi 1, 5, dan $10 \%$ dari berat total bahan baku (Tabel 1). Beras analog tanpa penambahan hidrokoloid digunakan sebagai kontrol (Ko).

Tabel 1. Penambahan hidrokoloid untuk setiap sampel

\begin{tabular}{lcc}
\hline \multirow{2}{*}{ Kode Sampel } & \multicolumn{2}{c}{ Konsentrasi hidrokoloid (\%) } \\
\cline { 2 - 3 } & K-karagenan & Konjak \\
\hline $\mathrm{Kr}_{1}$ & 1,0 & - \\
$\mathrm{Kr}_{5}$ & 5,0 & - \\
$\mathrm{Kr}_{10}$ & 10,0 & - \\
$\mathrm{Kj}_{1}$ & - & 1,0 \\
$\mathrm{Kj}_{5}$ & - & 5,0 \\
$\mathrm{Kj}_{10}$ & - & 10,0 \\
$\mathrm{KK}_{1}$ & 0,5 & 0,5 \\
$\mathrm{KK}_{5}$ & 2,5 & 2,5 \\
$\mathrm{KK}_{10}$ & 5,0 & 5,0 \\
Kontrol (Ko) & - & - \\
\hline
\end{tabular}

Pencampuran bahan dan air dilakukan di dalam mixer selama 15 menit, lalu campuran bahan dimasukkan ke dalam hopper untuk diumpankan ke dalam ekstruder. Ekstruder diatur pada suhu feeding 50 ${ }^{\circ} \mathrm{C}$, suhu kneading $80{ }^{\circ} \mathrm{C}$ dan suhu final cooking zone $90{ }^{\circ} \mathrm{C}$, dengan kecepatan ulir $40 \mathrm{~Hz}$. Ekstrudat berupa beras analog ditempatkan pada tray dan dikeringkan dalam pengering kabinet bersuhu $60^{\circ} \mathrm{C}$ selama 2 jam (hingga kadar air 12\%). Setelah kering, beras analog diangin-anginkan hingga mencapai suhu ruangan. Beras analog yang dihasilkan kemudian direbus selama 1 menit, lalu ditiriskan dan dikukus selama 15 menit sambil sesekali diaduk. Nasi kemudian dikeringkan dengan fluidized bed dryer pada suhu $130^{\circ} \mathrm{C}$ selama 10 menit, dilanjutkan dengan pendinginan dengan blower selama 2 menit.

Beras analog instan yang dihasilkan dianalisis sifat fisiknya yang meliputi densitas kamba, degree of breakage, dan struktur morfologinya. Beras analog instan lalu direndam dalam air mendidih untuk pengamatan keutuhan butiran nasi dan pengujian waktu rehidrasi, kapasitas rehidrasi, dan tekstur nasi setelah rehidrasi.

\section{Densitas Kamba}

Sampel dimasukkan ke dalam gelas ukur $25 \mathrm{~mL}$. Gelas ukur diketuk-ketukkan ke meja selama 1 menit dan sampel terus dimasukkan hingga volume tepat mencapai $25 \mathrm{~mL}$. Bobot sampel kemudian ditimbang dan densitas kamba dihitung sebagai perbandingan antara bobot $(\mathrm{g})$ dan volume sampel $(\mathrm{mL})$ (Wongsa dkk., 2017).

\section{Degree of Breakage}

Keutuhan butiran beras analog instan dinyatakan dalam degree of breakage (Bui dkk., 2018). Sebanyak $10 \mathrm{~g}$ sampel diambil secara acak, lalu dipisahkan antara butiran pecah dan butiran yang utuh. Kelompok butiran pecah ditimbang. Persentase bobot butiran pecah terhadap bobot sampel keseluruhan dinyatakan sebagai nilai degree of breakage, yang merupakan rata-rata dari empat kali ulangan.

\section{Waktu Rehidrasi}

Waktu rehidrasi ditentukan melalui pengepresan beras analog instan yang telah direhidrasi pada dua buah lempeng kaca (Wongsa dkk., 2016). Sebanyak $50 \mathrm{~mL}$ air mendidih dituangkan ke dalam gelas piala berisi $2 \mathrm{~g}$ beras analog instan, lalu ditutup dengan gelas arloji. Setiap 30 detik, 10 butir sampel diambil dan diletakkan di atas lempeng kaca, dan sampel ditekan dengan lempeng kaca kedua. Waktu rehidrasi (menit) ditentukan apabila inti putih di bagian tengah butiran 
nasi telah hilang atau nasi tampak translusen. Pengujian dilakukan terhadap sampel beras analog instan dan beras analog non-instan.

\section{Kapasitas Rehidrasi}

Kapasitas rehidrasi ditentukan dengan menambahkan $50 \mathrm{~mL}$ air mendidih ke dalam $2 \mathrm{~g}$ sampel beras analog instan, dan dibiarkan selama waktu rehidrasi yang telah ditentukan sebelumnya. Air rendaman dibuang, lalu sampel ditiriskan dan ditimbang. Persen rasio antara bobot nasi sebelum dan setelah direhidrasi merupakan nilai kapasitas rehidrasi sampel (dari rata-rata dua kali ulangan) (Bui dkk., 2018).

\section{Texture Profile Analysis}

Sebanyak $30 \mathrm{~mL}$ air mendidih ditambahkan ke dalam gelas piala berisi $3 \mathrm{~g}$ sampel beras analog instan, lalu gelas piala ditutup dengan gelas arloji. Setelah mencapai waktu rehidrasi yang telah ditentukan sebelumnya, sampel ditiriskan, dipindahkan ke dalam wadah bertutup, kemudian dimasukkan ke dalam penangas air bersuhu $30^{\circ} \mathrm{C}$ selama 10 menit. Tekstur nasi diukur dengan texture analyzer menggunakan metode texture profile analysis (TPA), yaitu dengan menekan sampel sebanyak dua kali. Instrumen diatur dengan pre-test $1 \mathrm{~mm} /$ detik, test speed dan post test $0,5 \mathrm{~mm} /$ detik, serta kompresi sejauh $60 \%$ dengan probe aluminium silinder berdiameter $36 \mathrm{~mm}$ (Hsu dkk., 2015). Pengujian dilakukan terhadap tiga butir sampel nasi (sebanyak delapan kali ulangan). Parameter tekstur nasi yang dianalisis berupa hardness, springiness, dan chewiness.

\section{Analisis Morfologi}

Morfologi dari sampel beras analog instan diamati menggunakan SEM. Satu butir sampel utuh dan sampel yang telah dipotong melintang ditempelkan pada aluminium stubs menggunakan perekat karbon konduktif, lalu dilapisi dengan platinum setebal $10 \mathrm{~nm}$ dengan arus $30 \mathrm{~mA}$. Keadaan morfologi permukaan dan mikrostruktur dari potongan cross-sectional sampel diamati pada perbesaran 35 kali.

\section{Rancangan Percobaan dan Analisis Statistika}

Penelitian menggunakan rancangan acak lengkap faktorial dua faktor (jenis dan konsentrasi hidrokoloid) yang masing-masing memiliki tiga taraf. Data yang diperoleh dianalisa dengan analysis of varians (ANOVA) dan uji lanjut menggunakan Duncan dengan tingkat kepercayaan 95\%. Analisis data dilakukan dengan perangkat lunak SPSS 22 for Windows.

\section{HASIL DAN PEMBAHASAN}

\section{Karakteristik Fisik Beras Analog Instan}

\section{Densitas Kamba}

Densitas kamba merupakan salah satu parameter fisik dari beras analog instan. Densitas kamba yang rendah menunjukkan produk yang berongga atau berpori, sedangkan densitas kamba yang tinggi mengindikasikan struktur produk yang padat (Boukouvalas dkk., 2006). Butiran beras analog instan yang lebih berpori mempermudah masuknya molekul air ke bagian tengah beras saat proses rehidrasi, sehingga mempercepat waktu rehidrasi (Wongsa dkk., 2017). Tabel 2 menunjukkan bahwa beras analog kontrol memiliki densitas kamba $0,53 \mathrm{~g} / \mathrm{mL}$, tidak berbeda nyata dengan beras analog instan dengan penambahan $\mathrm{k}$-karagenan $1,0 \%\left(\mathrm{Kr}_{1}\right)$ atau kombinasi $\mathrm{k}$-karagenan dan konjak masing-masing 0,5\% $\left(\mathrm{KK}_{1}\right)$. Peningkatan konsentrasi k-karagenan dan konjak, baik secara tunggal maupun kombinasi menunjukkan pola penurunan densitas kamba beras analog instan. Hal ini diduga berkaitan dengan semakin banyaknya gugus hidrofilik dari k-karagenan dan konjak di dalam butiran beras analog instan yang dapat mengikat air saat proses pemasakan. Air yang terikat ini kemudian dihilangkan melalui proses pengeringan, menghasilkan ronggarongga di dalam butiran beras analog instan, dan menurunkan densitas kamba. Pemberian k-karagenan dan konjak secara kombinasi menghasilkan densitas

Tabel 2. Karakteristik beras instan dengan penambahan к-karagenan dan konjak

\begin{tabular}{ccc}
\hline $\begin{array}{c}\text { Kode } \\
\text { sampel }\end{array}$ & $\begin{array}{c}\text { Densitas kamba } \\
(\mathrm{g} / \mathrm{mL})\end{array}$ & $\begin{array}{c}\text { Degree of breakage } \\
(\%)\end{array}$ \\
\hline $\mathrm{Kr}_{1}$ & $0,53 \pm 0,00^{\mathrm{b}}$ & $13,70 \pm 0,37^{\mathrm{c}}$ \\
$\mathrm{Kr}_{5}$ & $0,51 \pm 0,01^{\mathrm{c}}$ & $8,48 \pm 0,05^{\mathrm{d}}$ \\
$\mathrm{Kr}_{10}$ & $0,44 \pm 0,00^{\mathrm{d}}$ & $1,96 \pm 0,11^{\mathrm{e}}$ \\
$\mathrm{Kj}_{1}$ & $0,56 \pm 0,01^{\mathrm{a}}$ & $16,90 \pm 0,39^{\mathrm{b}}$ \\
$\mathrm{Kj}_{5}$ & $0,54 \pm 0,01^{\mathrm{a}}$ & $14,30 \pm 0,36^{\mathrm{c}}$ \\
$\mathrm{Kj}_{10}$ & $0,51 \pm 0,00^{\mathrm{c}}$ & $17,52 \pm 0,01^{\mathrm{b}}$ \\
$\mathrm{KK}_{1}$ & $0,52 \pm 0,01^{\mathrm{b}}$ & $32,70 \pm 0,71^{\mathrm{a}}$ \\
$\mathrm{KK}_{5}$ & $0,50 \pm 0,01^{\mathrm{c}}$ & $7,51 \pm 0,06^{\mathrm{d}}$ \\
$\mathrm{KK}_{10}$ & $0,39 \pm 0,00^{\mathrm{e}}$ & $2,02 \pm 0,01^{\mathrm{e}}$ \\
$\mathrm{Kontrol}^{\mathrm{a}}$ & $0,53 \pm 0,00^{\mathrm{b}}$ & $33,58 \pm 0,82^{\mathrm{a}}$ \\
\hline
\end{tabular}

Data disajikan sebagai rataan \pm standar deviasi; angka-angka pada kolom yang sama yang diiikuti oleh huruf yang sama tidak berbeda nyata pada tarah uji 5\% (uji Duncan) 
kamba yang lebih rendah dibandingkan beras analog instan dengan penambahan hidrokoloid secara tunggal. Densitas kamba terendah $(0,39 \mathrm{~g} / \mathrm{mL})$ ditunjukkan oleh beras analog instan dengan penambahan $\mathrm{k}$-karagenan dan konjak masing-masing $5 \%\left(\mathrm{KK}_{10}\right)$.

\section{Degree of Breakage}

Beras analog instan diharapkan memiliki penampakan butiran yang utuh dengan jumlah butiran patah/pecah yang sedikit. Tanpa penambahan k-karagenan dan konjak, beras analog instan yang dihasilkan rapuh dan mudah patah, sehingga memiliki nilai degree of breakageyang tinggi, yaitu 33,58\% (Tabel 2). Nilai ini turun dengan penambahan $\mathrm{k}$-karagenan dan/atau konjak. Penambahan 1\% k-karagenan secara tunggal telah mampu menurunkan degree of breakage secara nyata. Degree of breakage ini semakin menurun dengan semakin meningkatnya konsentrasi k-karagenan. Pola ini tidak tampak pada penambahan konjak secara tunggal. Penambahan konjak konsentrasi 1, 5, dan $10 \%$ menghasilkan degree of breakage yang tidak jauh berbeda satu sama lain, yaitu 16,90; 14,30; dan 17,52\%. Penambahan $\mathrm{k}$-karagenan dan konjak secara kombinasi juga mampu menurunkan degree of breakage, namun penurunan baru terlihat pada konsentrasi $5 \%$ dan $10 \%$ kombinasi k-karagenan dan konjak. Penurunan degree of breakage yang sangat besar terlihat pada penambahan $5 \%$ karagenan dan konjak secara kombinasi, yaitu dari $32,70 \%\left(\mathrm{KK}_{1}\right)$ menjadi $7,51 \%\left(\mathrm{KK}_{5}\right)$. Nilai ini semakin menurun dengan meningkatnya konsentrasi karagenan dan konjak, yaitu menjadi 2,02\% pada sampel $\mathrm{KK}_{10}$.
Kerja karagenan sebagai binder dalam proses ekstrusi diduga memberi dampak terhadap keutuhan butiran beras analog instan. Nilai degree of breakage yang lebih besar tampak dimiliki oleh sampel beras tanpa penambahan karagenan (kontrol dan kelompok $\mathrm{Kj}$ ) dibandingkan dengan beras analog instan dengan penambahan karagenan (kelompok Kr dan KK). Degree of breakage dari beras analog instan yang diperoleh dalam penelitian ini termasuk rendah jika dibandingkan dengan penelitian Bui dkk. (2018) yang melakukan proses instanisasi beras Basmati dengan proses pengukusan dan dilanjutkan dengan freeze drying. Beras instan pada penelitian tersebut memiliki degree of breakage sebesar 33,6\%.

\section{Kemampuan Rehidrasi}

Beras analog instan diharapkan memiliki kemampuan rehidrasi yang baik yang ditunjukkan dengan waktu rehidrasi yang cepat, kapasitas rehidrasi yang tinggi, dan mampu mempertahankan keutuhan bentuk butiran nasi setelah direhidrasi. Tabel 3 menunjukkan kemampuan rehidrasi beras analog instan setelah direndam dengan air mendidih. Semua sampel beras analog instan memiliki waktu rehidrasi yang pendek dan memenuhi definisi beras instan, yaitu memiliki waktu rehidrasi di bawah 5 menit (Patent No. US 2001/0006696 A1, 2001). Waktu rehidrasi beras analog instan ini jauh lebih cepat dibandingkan dengan beras analog noninstan yang membutuhkan waktu rehidrasi selama 20 menit jika hanya direndam dalam air mendidih, dan jika dimasak dengan rice cooker membutuhkan waktu

Tabel 3. Kemampuan rehidrasi nasi instan

\begin{tabular}{cccc}
\hline Kode sampel & $\begin{array}{c}\text { Waktu rehidrasi } \\
(\text { menit })\end{array}$ & $\begin{array}{c}\text { Kapasitas rehidrasi } \\
(\%)^{*}\end{array}$ & $\begin{array}{c}\text { Keutuhan bentuk nasi } \\
\text { setelah rehidrasi }\end{array}$ \\
\hline $\mathrm{Kr}_{1}$ & 4,5 & $162,38 \pm 2,41^{\mathrm{f}}$ & ++ \\
$\mathrm{Kr}_{5}$ & 4,0 & $174,29 \pm 2,20^{\mathrm{e}}$ & +++ \\
$\mathrm{Kr}_{10}$ & 4,0 & $252,62 \pm 2,65^{\mathrm{a}}$ & ++++ \\
$\mathrm{Kj}_{1}$ & 4,5 & $147,24 \pm 0,94^{\mathrm{a}}$ & ++ \\
$\mathrm{Kj}_{5}$ & 4,0 & $177,50 \pm 0,28^{\mathrm{de}}$ & ++ \\
$\mathrm{Kj}_{10}$ & 3,5 & $198,39 \pm 3,00^{\mathrm{c}}$ & +++ \\
$\mathrm{KK}_{1}$ & 4,0 & $210,10 \pm 3,88^{\mathrm{b}}$ & + \\
$\mathrm{KK}_{5}$ & 4,0 & $180,81 \pm 4,37^{\mathrm{d}}$ & ++ \\
$\mathrm{KK}_{10}$ & 3,5 & $196,10 \pm 2,92^{\mathrm{c}}$ & +++++ \\
$K$ & 4,0 & $144,83 \pm 1,12^{\mathrm{g}}$ & ++ \\
Ko & 20,0 & - & ++ \\
\hline
\end{tabular}

*Data disajikan sebagai rataan \pm standar deviasi; angka-angka pada kolom yang sama yang diikuti oleh huruf yang sama tidak berbeda nyata pada taraf uji 5\% (uji Duncan) 
penanakan selama \pm 5 menit (Noviasari dkk., 2017a). Beras analog instan yang diperoleh dalam penelitian ini juga memiliki waktu rehidrasi yang lebih cepat dari beras analog instan dengan penambahan $1 \%$ natrium alginat, yang membutuhkan waktu rehidrasi selama 15 menit (Herawati, 2015). K-karagenan dan konjak yang ditambahkan di dalam formula beras analog instan disusun oleh gugus-gugus hidrofilik yang banyak, yang dapat meningkatkan penyerapan air saat proses rehidrasi. Selain itu, struktur butiran beras yang berpori juga berperan dalam menyediakan jalan untuk masuknya air ke dalam butiran beras, dan mempercepat waktu rehidrasi (Bui dkk., 2018; Rewthong dkk., 2011).

Kapasitas rehidrasi menunjukkan seberapa banyak butiran beras analog instan mampu menyerap air saat proses rehidrasi. Tabel 3 menunjukkan kapasitas rehidrasi terendah dimiliki oleh beras analog instan kontrol (144,83\%), diikuti dengan beras analog dengan penambahan $1 \%$ konjak $(147,24 \%)$. Kedua sampel ini memiliki densitas kamba yang relatif tinggi dibandingkan sampel lainnya (Tabel 2). Penelitian Prasert dan Suwannaporn (2009) menunjukkan adanya korelasi negatif antara nilai kapasitas rehidrasi dengan densitas kamba beras instan. Hal tersebut berkaitan dengan semakin luasnya permukaan pada beras dengan densitas kamba yang rendah, sehingga memungkinkan lebih banyaknya air untuk dapat terserap masuk ke dalam butiran beras saat proses rehidrasi. Selain itu, kapasitas rehidrasi juga diduga dipengaruhi oleh daya hidrasi dari k-karagenan dan konjak yang ditambahkan dalam formula beras analog instan. Pada tabel 3, terlihat bahwa penambahan $\mathrm{k}$-karagenan secara tunggal menghasilkan kapasitas rehidrasi yang sedikit lebih tinggi dibandingkan dengan penambahan konjak. Hal ini diduga dipengaruhi oleh perbedaan jenis muatan antara $\mathrm{k}$-karagenan dan konjak. K-karagenan diketahui memiliki muatan negatif, sedangkan konjak merupakan hidrokoloid yang tidak bermuatan. Polisakarida bermuatan negatif cenderung memiliki daya hidrasi yang lebih besar daripada polisakarida netral (Marthur, 2012).

Pada penambahan $\mathrm{K}$-karagenan dan konjak secara kombinasi, konsentrasi $1 \%\left(\mathrm{KK}_{1}\right)$ telah mampu meningkatkan kapasitas rehidrasi beras analog instan menjadi $210,10 \%$. Namun, kemampuan penyerapan air $\mathrm{KK}_{1}$ yang tinggi ini tidak diimbangi dengan kekuatan butiran nasi dalam menjaga keutuhan bentuknya, sehingga sebagian besar nasi pecah saat direhidrasi. Sementara itu, penambahan 10\% $\mathrm{k}$-karagenan menunjukkan nilai kapasitas rehidrasi yang paling tinggi dibandingkan formula lain (252,62\%), serta kemampuan mempertahankan keutuhan bentuk butiran nasi yang juga sangat baik. Secara keseluruhan, pengujian yang dilakukan menunjukkan kapasitas rehidrasi nasi instan dengan urutan kelompok KK>Kr>Kj>Ko (Tabel 3).

\section{Struktur Morfologi}

Gambar 1 memperlihatkan bentuk morfologi dan kondisi mikrostruktur beras analog instan kontrol (Ko) dan dengan penambahan $\mathrm{k}$-karagenan dan/atau konjak pada konsentrasi tertinggi (10\%). Pada pengamatan menggunakan perbesaran 35 kali, tidak terlihat adanya perbedaan yang nyata pada bagian permukaan beras analog instan pada keempat sampel. Pada foto cross section, beras analog kontrol tampak memiliki struktur yang paling padat dibandingkan dengan beras analog yang diberi tambahan $\mathrm{k}$-karagenan dan/atau konjak. Terdapat rongga sempit yang tidak sebesar dan sebanyak $\mathrm{Kr}_{10}, \mathrm{Kj}_{10}$, dan $\mathrm{KK}_{10}$. Gambaran ini sesuai dengan nilai densitas kamba beras analog instan kontrol yang paling tinggi dibandingkan ketiga beras analog instan yang lain.

Pada beras analog instan dengan penambahan K-karagenan dan konjak secara tunggal $\left(\mathrm{Kr}_{10}\right.$ dan $\left.\mathrm{Kj}_{10}\right)$, tampak adanya rongga-rongga besar dan kecil di bagian tengah butiran beras. Rongga-rongga ini berukuran lebih besar dibandingkan dengan rongga pada beras analog instan kontrol. Rongga pada bagian tengah beras analog instan terbentuk dengan lebih besar lagi pada penambahan $\mathrm{k}$-karagenan dan konjak secara kombinasi $\left(\mathrm{KK}_{10}\right)$. Rongga ini menyebabkan lebih rendahnya nilai densitas kamba beras instan $\mathrm{KK}_{10}$ dibandingkan formula lain, sedangkan bagian periferal yang padat dapat menjelaskan kokohnya butiran beras instan dengan nilai degree of breakage yang rendah. Bagian periferal yang padat ini juga diduga memberikan pengaruh terhadap peningkatan nilai hardness dari nasi setelah rehidrasi. Namun demikian, Rewthong dkk. (2011) menunjukkan bahwa untuk dapat memperoleh kualitas tekstur seperti nasi yang dimasak secara konvensional, butiran beras instan harus memiliki pori-pori kecil yang menyebar merata pada seluruh bagian tengah beras. Rongga besar dengan bagian periferal yang padat seperti yang terlihat pada gambaran SEM beras instan $\mathrm{KK}_{10}$ disebabkan oleh terjadinya case hardening. Proses pengeringan yang terlalu cepat menyebabkan bagian terluar dari butiran nasi menjadi kering terlebih dahulu, membentuk lapisan keras yang kemudian menghambat keluarnya air dari bagian tengah nasi. Uap air yang terjebak di bagian tengah nasi kemudian menekan struktur sel ke arah permukaan, sehingga membentuk rongga berukuran besar pada bagian tengah nasi yang telah kering (Gulati dan Datta, 2015). Rongga besar ini dapat melemahkan struktur nasi setelah direhidrasi dan dapat menyebabkan nasi menjadi lembek (Bui dkk., 2018). 


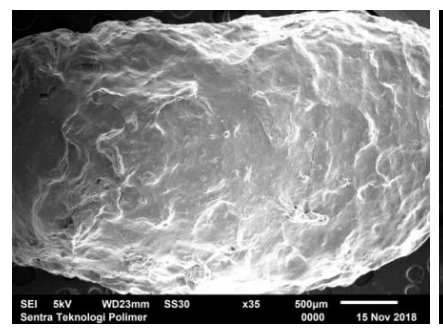

(a)

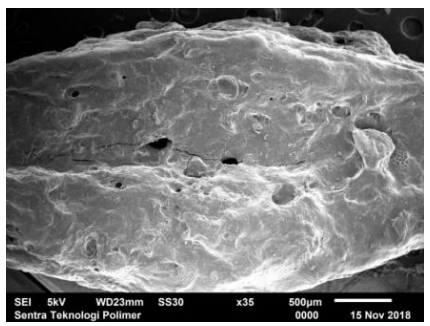

(c)

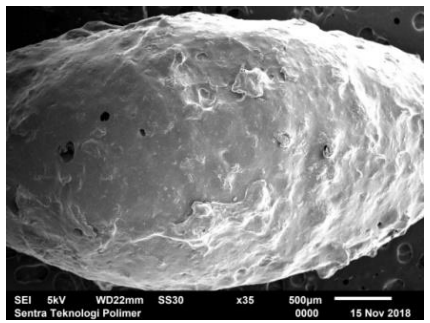

(e)

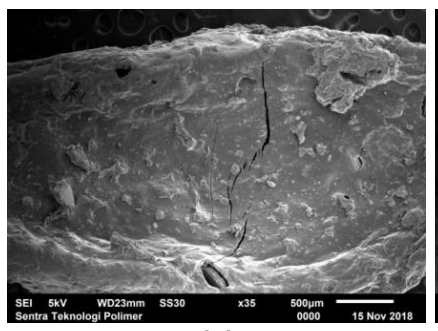

(g)

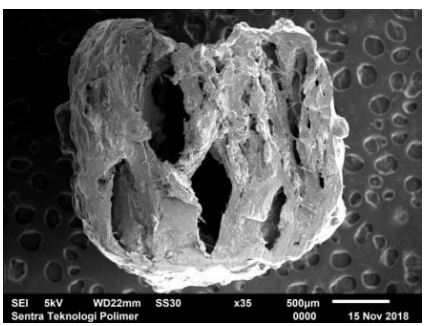

(b)

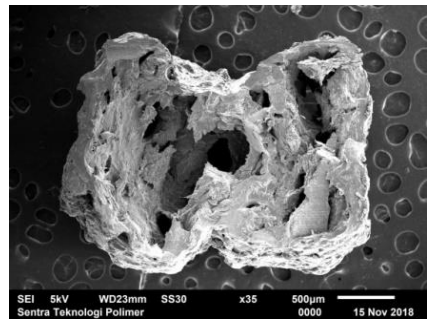

(d)

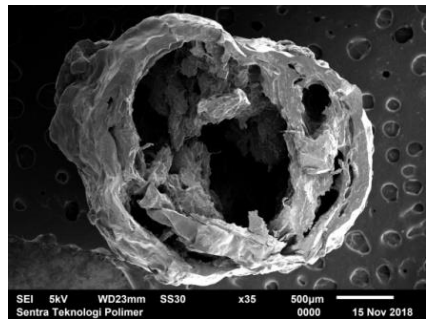

(f)

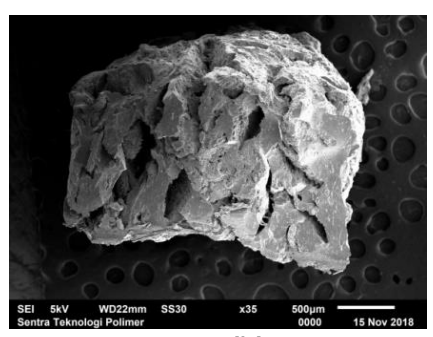

(h)
Gambar 1. Hasil analisa SEM beras analog instan dengan perbesaran 35x: permukaan $\mathrm{Kr}_{10}$ (a), cross section $\mathrm{Kr}_{10}$ (b), permukaan $\mathrm{Kj}_{10}(\mathrm{c})$, cross section $\mathrm{Kj}_{10}(\mathrm{~d})$, permukaan $\mathrm{KK}_{10}(\mathrm{e})$, cross section $\mathrm{KK}_{10}(\mathrm{f})$, permukaan $\mathrm{Ko}(\mathrm{g})$; cross section Ko $(\mathrm{h})$

\section{Karakteristik Fisik Nasi Analog Instan Setelah Direhidrasi}

\section{Penampakan visual}

Gambar 2 menunjukkan penampakan visual seluruh sampel nasi instan setelah direndam dalam air mendidih. Nasi tanpa penambahan k-karagenan dan konjak (Ko) tampak tipis, kurang mengembang dan mudah patah. Penambahan dan peningkatan konsentrasi $\mathrm{k}$-karagenan dan konjak secara tunggal terlihat mampu meningkatkan keutuhan bentuk butiran nasi. Pada tingkat konsentrasi yang sama, nasi dengan penambahan $\mathrm{k}$-karagenan menunjukkan keutuhan bentuk yang lebih baik dibandingkan dengan penambahan konjak. Nasi dengan penambahan $10 \%$ $\mathrm{k}$-karagenan $\left(\mathrm{Kr}_{10}\right)$ mengalami pengembangan volume tertinggi, sesuai dengan nilai kapasitas rehidrasi $\mathrm{Kr}_{10}$ yang paling tinggi dibandingkan formula lain (Tabel 3). Penambahan $\mathrm{k}$-karagenan dan konjak secara kombinasi pada konsentrasi $1 \%$ menghasilkan nasi yang lembek dan mudah hancur. Nasi tampak utuh dan kokoh pada penambahan $\mathrm{k}$-karagenan dan konjak secara kombinasi pada konsentrasi $10 \%\left(\mathrm{KK}_{10}\right)$. Formula ini menghasilkan nasi dengan penampakan visual terbaik, dengan keutuhan bentuk yang tertinggi. Jika dibandingkan dengan nasi analog non-instan yang dimasak dengan menggunakan rice cooker yang dilaporkan (Noviasari dkk., 2013), penampakan bentuk butiran nasi $\mathrm{KK}_{10}$ tidak jauh berbeda, akan tetapi butiran nasi $\mathrm{KK}_{10}$ tampak lebih terpisah satu sama lain, berbeda dengan nasi analog non-instan yang saling menempel.

\section{Texture profile analysis}

Jenis dan konsentrasi hidrokoloid berpengaruh nyata terhadap nilai hardness nasi setelah direhidrasi (Gambar 3a). Penambahan 1\% K-karagenan dan konjak, baik secara tunggal maupun kombinasi, menghasilkan nasi dengan nilai hardness di bawah nilai kontrol. Pada tingkat konsentrasi ini, tampaknya kemampuan penyerapan air yang tinggi tidak diimbangi dengan kekuatan struktur nasi dalam menjaga keutuhan bentuk butirannya, sehingga tidak mampu menahan tekanan yang diberikan. Sementara itu, penambahan 5\% k-karagenan dan konjak secara kombinasi menunjukkan peningkatan nilai hardness dengan drastis. Pada tingkat konsentrasi hidrokoloid 5\% ini, terlihat adanya efek sinergisme antara $\mathrm{k}$-karagenan dan konjak, yang meningkatkan hardness nasi jauh lebih tinggi dibandingkan pada penambahan $\mathrm{k}$-karagenan dan konjak secara tunggal. Efek sinergisme ini dilaporkan juga oleh Kaya dkk. (2015) yang menunjukkan terbentuknya gel dengan kekuatan tinggi dan elastis akibat terabsorpsinya molekul konjak glukomanan ke permukaan junction zone dari molekul $\mathrm{k}$-karagenan, yang menyebabkan terjadinya penggabungan $\mathrm{k}$-karagenan dan konjak. Secara keseluruhan, nilai hardness tertinggi dimiliki oleh kelompok nasi instan $\mathrm{KK}$, diikuti oleh kelompok $\mathrm{Kr}$, dan $\mathrm{Kj}$. Semakin tinggi konsentrasi $\mathrm{k}$-karagenan dan konjak yang ditambahkan, semakin tinggi pula respons hardness nasi yang terukur.

Springiness merupakan parameter yang menunjukkan kemampuan suatu bahan untuk kembali ke posisi awal dari tingkat kompresi pada 


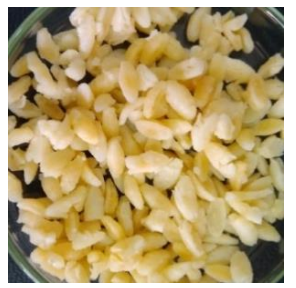

(a)

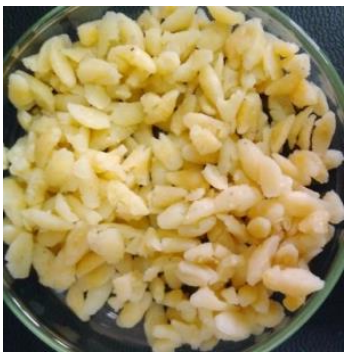

(d)

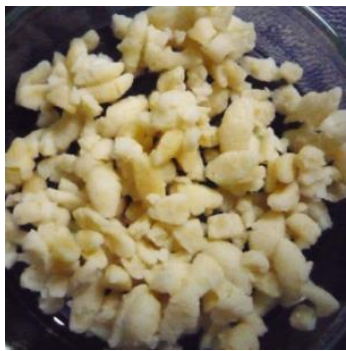

(g)

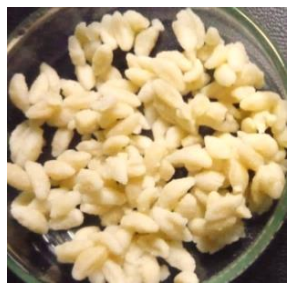

(b)

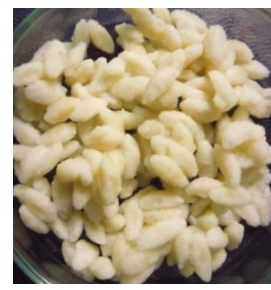

(c)

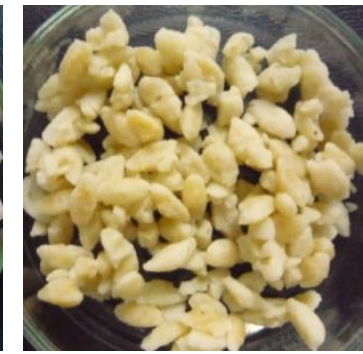

(e)

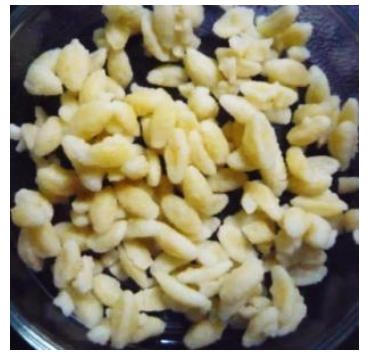

(h)

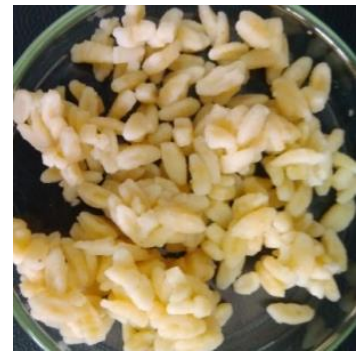

(f)

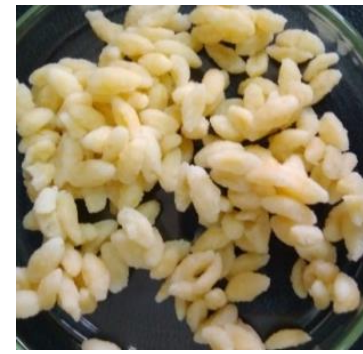

(i)

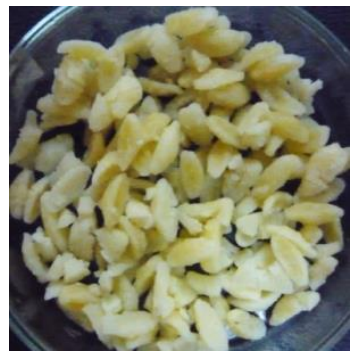

(j)

Gambar 2. Penampakan fisik nasi instan setelah direhidrasi: $\mathrm{Kr}_{1}(\mathrm{a}), \mathrm{Kr}_{5}(\mathrm{~b}), \mathrm{Kr}_{10}(\mathrm{c}), \mathrm{Kj}_{1}(\mathrm{~d}), \mathrm{Kj}_{5}(\mathrm{e}), \mathrm{Kj}_{10}(\mathrm{f}), \mathrm{KK}_{1}$ (g), $\mathrm{KK}_{5}(\mathrm{~h}), \mathrm{KK}_{10}(\mathrm{i}), \mathrm{Ko}(\mathrm{j})$

gigitan awal hingga ke gigitan kedua. Berdasarkan hasil analisis terhadap sepuluh formula beras instan setelah direhidrasi, nilai respon springiness memiliki rentang nilai antara 0,56 hingga 0,86 (Gambar 3b). Nilai springiness nasi kontrol tidak berbeda nyata dengan $\mathrm{KK}_{1}$, namun sedikit lebih tinggi dibandingkan dengan nasi $\mathrm{Kr}_{1}$ dan $\mathrm{Kj}_{1}$. Pada konsentrasi $5 \%$ dan $10 \%$, penambahan $\mathrm{k}$-karagenan secara tunggal dan kombinasi memberikan nilai springiness yang semakin tinggi, lebih tinggi dari kontrol. Namun demikian, hal ini tidak tercapai pada nasi analog dengan penambahan konjak. Penambahan konjak secara tunggal pada tiga tingkat konsentrasi menunjukkan nilai springiness yang tidak berbeda nyata.

Chewiness didefinisikan sebagai energi yang dibutuhkan untuk mengunyah makanan padat hingga siap untuk ditelan. Nilai chewiness dihitung dari hasil perkalian antara nilai hardness, cohesiveness, dan springinesspada uji TPA. Perbedaan jenis dan konsentrasi hidrokoloid memberikan pengaruh nyata terhadap tingkat chewiness produk (Gambar 3c). Terlihat adanya pola peningkatan nilai chewiness dengan semakin meningkatnya konsentrasi k-karagenan dan konjak $(1 \%-10 \%)$, baik yang ditambahkan secara tunggal maupun kombinasi. Namun demikian, penambahan konjak secara tunggal pada semua tingkat konsentrasi menunjukkan nilai chewiness yang lebih rendah atau sama dengan kontrol. Penambahan k-karagenan dan konjak secara kombinasi memberikan nilai chewiness yang tertinggi dibandingkan kelompok lain. Respons chewiness tertinggi dimiliki oleh nasi instan formula $\mathrm{KK}_{10}$ dengan nilai $220,76 \mathrm{~g}$ dan nilai terendah dimiliki oleh formula $\mathrm{Kj}_{1}$ dengan nilai $50,50 \mathrm{~g}$.

Secara keseluruhan, hardness, springiness, dan chewiness nasi instan setelah rehidrasi, menunjukkan peningkatan dengan semakin bertambahnya persentase k-karagenan dan konjak yang ditambahkan ke dalam formula (Gambar 3). Hal ini sejalan dengan hasil penelitian Wongsa dkk. (2017) yang menambahkan gum arabik sebanyak $2 \%, 4 \%$, dan $6 \%$ ke dalam formula beras instan berbahan tepung beras dengan proses ekstrusi. Penelitian tersebut menunjukkan 


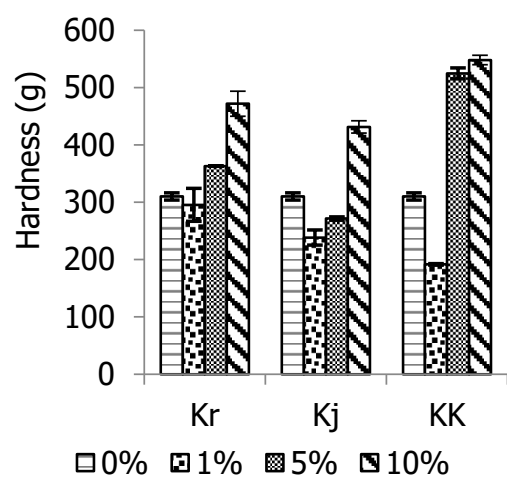

(a)

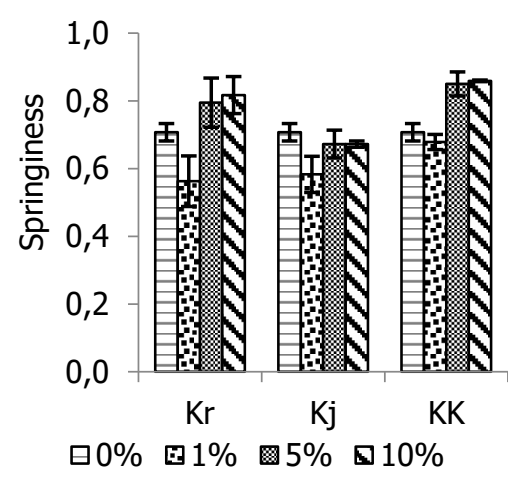

(b)

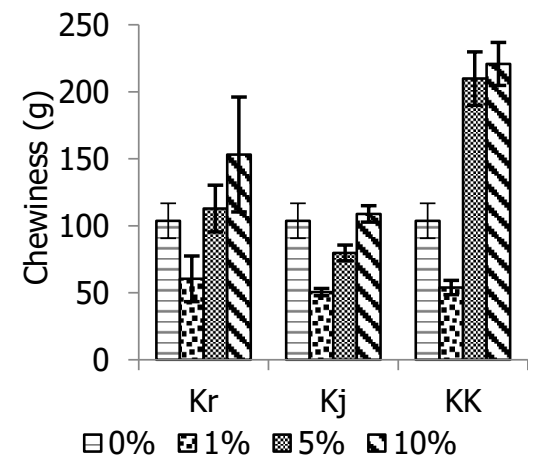

(c)

Gambar 3. Grafik tekstur nasi instan setelah direhidrasi: hardness (a), springiness (b) dan chewiness (c)

semakin tingginya semua respons TPA dengan semakin meningkatnya konsentrasi gum arabik. Tekstur nasi yang diperoleh pada penelitian ini masih belum bisa menyamai tekstur nasi yang dimasak secara konvensional. Salah satu hal yang diduga menyebabkan hal ini adalah terbentuknya rongga besar di bagian tengah beras akibat proses instanisasi, seperti yang terlihat pada hasil analisa SEM potongan melintang beras analog instan (Gambar 1). Rongga besar pada bagian tengah beras instan dapat melemahkan struktur nasi setelah direhidrasi dan menghasilkan nasi yang lembek dengan respons springiness yang rendah, seperti yang dilaporkan oleh Bui dkk. (2018). Oleh karena itu, penelitian lanjutan masih perlu dilakukan untuk mengoptimasi proses pengeringan agar beras analog instan dapat kering secara merata, dengan rongga berukuran kecil merata di bagian tengah beras. Selain itu, perbaikan formula beras analog instan juga perlu dilakukan untuk meningkatkan kekuatan struktur butiran beras dan meningkatkan kualitas tekstur nasi secara keseluruhan.

\section{KESIMPULAN}

Penambahan $\mathrm{k}$-karagenan dan konjak secara kombinasi menghasilkan beras analog instan yang lebih baik dibandingkan dengan penambahan hidrokoloid tersebut secara tunggal. Konsentrasi $\mathrm{k}$-karagenan dan konjak yang semakin tinggi meningkatkan kemampuan rehidrasi, penampakan visual, dan tekstur nasi setelah direhidrasi. Beras analog instan terbaik diperoleh dengan penambahan kombinasi $\mathrm{k}$-karagenan 5,0\% dan konjak 5,0\% $\left(\mathrm{KK}_{10}\right)$. Beras analog instan tersebut memiliki penampakan visual yang lebih kokoh (tidak mudah hancur), baik sebelum dan setelah rehidrasi, respons tekstural yang lebih tinggi, dan waktu rehidrasi yang lebih singkat dibandingkan beras analog kontrol (tanpa penambahan $\mathrm{k}-k a r a g e n a n$ dan konjak).

\section{KONFLIK KEPENTINGAN}

Tidak ada konflik kepentingan dalam penelitian ini.

\section{DAFTAR PUSTAKA}

Blakemore, W. R. (2016). Polysaccharide Ingredients: Carrageenan. In Reference Module in Food Science. https://doi.org/10.1016/B978-0-08-100596-5.03251-0

Boukouvalas, C. J., Krokida, M. K., Maroulis, Z. B., \& Marinos-Louris, D. (2006). Density and porosity: literature data compilation for foodstuffs. International Journal of Food Properties, 9: 715-746. https://doi. org/10.1080/10942910600575690

Budijanto, S., Andri, Y. I., Faridah, D. N., \& Noviasari, S. (2017). Karakterisasi kimia dan efek hipoglikemik beras analog berbahan dasar jagung, sorgum, dan sagu aren. Agritech, 37(4): 402-409. https://doi.org/10.22146/ agritech.10383

Budijanto, S., \& Yuliana, N. D. (2015). Development of rice analog as a food diversification vehicle in Indonesia. Journal of Developments in Sustainable Agriculture, 10(1): 7-14. https://doi.org/10.11178/jdsa.10.7

Budijanto, S., \& Yuliyanti. (2012). Studi persiapan tepung sorgum (Sorghum bicolor L. Moench) dan aplikasinya pada pembuatan beras analog. Jurnal Teknologi Pertanian, 13(3): 177-186.

Bui, L. T. T., Coad, R. A., \& Stanley, R. A. (2018). Properties of rehydrated freeze dried rice as a function of processing treatments. LWT - Food Science and Technology, 91: 143-150. https://doi.org/10.1016/j.Iwt.2018.01.039 
Gulati, T., \& Datta, A. K. (2015). Mechanistic understanding of case-hardening and texture development during drying of food materials. Journal of Food Engineering, 166: 119138. https://doi.org/10.1016/j.jfoodeng.2015.05.031

Han, L., Cheng, Y., Zhang, Q., Tatsumi, E., \& Li, L. (2014). Synergistic effects of calcium hydroxide and konjac glucomannan (KGM) on the thermomechanical properties of buckwheat flour and the quality of buckwheat noodles. Journal of Texture Studies, 45: 420-429. https://doi. org/10.1111/jtxs.12093

Herawati, H. (2015). Optimasi Proses, Profil Isotermis Sorpsi Air dan Analisis Termal Beras Tiruan Instan. Institut Pertanian Bogor.

Hsu, R. J., Chen, H., Lu, S., \& Chiang, W. (2015). Effects of cooking, retrogradation and drying on starch digestibility in instant rice making. Journal of Cereal Science, 65: 154-161. https://doi.org/10.1016/j.jcs.2015.05.015

Kaya, A. O., Suryani, A., Santoso, J., \& Rusli, S. M. (2015). Karakteristik dan struktur mikro gel campuran semirefined carrageenan dan glukomanan. Jurnal Kimia Dan Kemasan, 37(1): 19-28.

Lee, E., \& Wissgott, U. (2001). Patent No. US 2001/0006696 A1. United States.

Marthur, N. K. (2012). Industrial Galactomannan Polysaccharides. Boca Raton: CRC Press.

Mishra, A., Mishra, H. N., \& Rao, P. S. (2012). Preparation of rice analogues using extrusion technology. International Journal of Food Science and Technology, 47: 1789-1797. https://doi.org/10.1111/j.1365-2621.2012.03035.x

Naligar, A. P. (2016). Formulasi dan Karakterisasi Puding Instan dengan Perbandingan Bahan Pembentuk Gel Kappa Karagenan dan Glukomanan. Universitas Pakuan.

Noviasari, S., Kusnandar, F., \& Budijanto, S. (2013). Pengembangan beras analog dengan memanfaatkan jagung putih. Jurnal Teknologi Dan Industri Pangan, 24(2): 194-200. https://doi.org/10.6066/ jtip.2013.24.2.194

Noviasari, S., Kusnandar, F., \& Setiyono, A. (2017a). Karakteristik fisik, kimia, dan sensori beras analog berbasis bahan pangan non beras. Pangan, 26(1): 1-12.

Noviasari, S., Kusnandar, F., Setiyono, A., \& Budijanto, S. (2015). Beras analog sebagai pangan fungsional dengan indeks glikemik rendah. Jurnal Gizi Dan Pangan, 10(3): 225-232. https://doi.org/10.25182/jgp.2015.10.3.

Noviasari, S., Widara, S. S., \& Budijanto, S. (2017b). Analogue rice as the vehicle of public nutrition diversity. Jurnal Kesehatan Masyarakat, 13(1), 19-27. https://doi. org/10.15294/kemas.v13i1. 8284

Penroj, P., Mitchell, J. R., Hill, S. E., \& Ganjanagunchorn, W. (2005). Effect of konjac glucomannan deacetylation on the properties of gels formed from mixtures of kappa carrageenan and konjac glucomannan. Carbohydrate
Polymers, 59, 367-376. https://doi.org/10.1016/j. carbpol.2004. 10.007

Prasert, W., \& Suwannaporn, P. (2009). Optimization of instant jasmine rice process and its physicochemical properties. Journal of Food Engineering, 95, 54-61. https://doi. org/10.1016/ j.jfoodeng.2009.04.008

Rasyid, M. I., Yuliana, N. D., \& Budijanto, S. (2017). Karakteristik sensori dan fisiko-kimia beras analog sorghum dengan penambahan rempah campuran. Agritech, 36(4): 394403. https://doi.org/10.22146/agritech.16762

Ratnawati, L., \& Afifah, N. (2018). Pengaruh penggunaan guar gum, carboxymethylcellulose (CMC) dan karagenan terhadap kualitas mi yang terbuat dari campuran mocaf, tepung beras dan tepung jagung. Pangan, 27(1): 43-54.

Rewthong, O., Soponronnarit, S., Taechapairoj, C., \& Tungtrakul, P. (2011). Effects of cooking , drying and pretreatment methods on texture and starch digestibility of instant rice. Journal of Food Engineering, 103(3): 258264. https://doi.org/10.1016/j.jfoodeng.2010.10.022

Tan, H., Tan, T., \& Easa, A. M. (2018). The use of selected hydrocolloids to enhance cooking quality and hardness of zero-salt noodles. International Journal of Food Science and Technology: 1-8. https://doi.org/10.1111/ ijfs. 13742

Wahjuningsih, S. B., \& Susanti, S. (2018). Chemical, physical, and sensory characteristics of analog rice developed from the mocaf, arrowroof, and red bean flour. IOP Conf. Series: Earth and Environmental Science: 1-10. https:// doi.org/doi :10.1088/1755-1315/102/1/012015

Wang, J. P., An, H. Z., Jin, Z. Y., Xie, Z. J., Zhuang, H. N., \& Kim, J. M. (2013). Emulsifiers and thickeners on extrusioncooked instant rice product. Journal of Food Science and Technology, 50(4): 655-666. https://doi.org/10.1007/ s13197-011-0400-6

Wongsa, J., Rungsardthong, V., Uttapap, D., Lamsal, B. P., \& Puttanlek, C. (2017). Effect of extrusion conditions, monoglyceride and gum arabic addition on physical and cooking properties of extruded instant rice. KMUTNB International Journal of Applied Science and Technology $x(\mathrm{x}):$ 1-8. https://doi.org/10.14416/j.ijast.2017.02.006

Wongsa, J., Uttapap, D., Lamsal, B. P., \& Rungsardthong, V. (2016). Effect of puffing conditions on physical properties and rehydration characteristic of instant rice product. International Journal of Food Science and Technology, 51: 672-680. https://doi.org/10.1111/ijfs.13011

Zhou, Y., Cao, H., Hou, M., Nirasawa, S., Tatsumi, E., Foster, T. J., \& Cheng, Y. (2013). Effect of konjac glucomannan on physical and sensory properties of noodles made from low-protein wheat flour. Foor Research International, 51(2): $\quad 879-885 . \quad \mathrm{https}: / /$ doi.org/10.1016/j. foodres.2013.02.002 